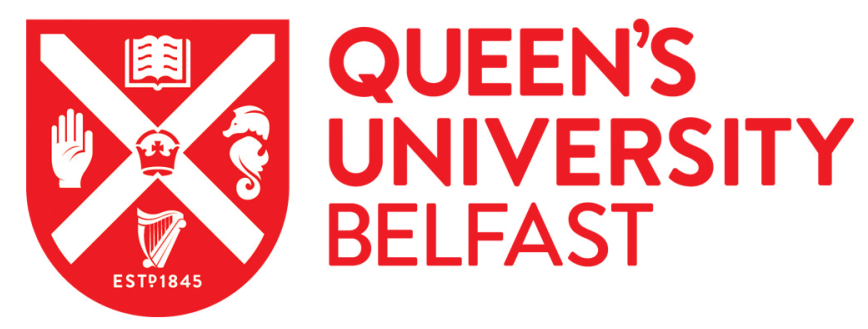

\title{
From the past to the Future: integrating archaeology and conflict resolution in Northern Ireland
}

Horning, A., Breen, C., \& Brannon, N. (2015). From the past to the Future: integrating archaeology and conflict resolution in Northern Ireland. Conservation and Management of Archaeological Sites, 17(1), 5-21. https://doi.org/10.1179/1350503315Z.00000000090

\section{Published in:}

Conservation and Management of Archaeological Sites

\section{Document Version:}

Peer reviewed version

Queen's University Belfast - Research Portal:

Link to publication record in Queen's University Belfast Research Portal

\section{Publisher rights}

(C) 2015 Copyright Informa UK Limited.

This work is made available online in accordance with the publisher's policies. Please refer to any applicable terms of use of the publisher.

\section{General rights}

Copyright for the publications made accessible via the Queen's University Belfast Research Portal is retained by the author(s) and / or other copyright owners and it is a condition of accessing these publications that users recognise and abide by the legal requirements associated with these rights.

Take down policy

The Research Portal is Queen's institutional repository that provides access to Queen's research output. Every effort has been made to ensure that content in the Research Portal does not infringe any person's rights, or applicable UK laws. If you discover content in the Research Portal that you believe breaches copyright or violates any law, please contact openaccess@qub.ac.uk. 
From the past to the future: Integrating archaeology and conflict resolution in Northern Ireland

Conservation and Management of Archaeological Sites 17 (2015).

Audrey Horning (Queen's University Belfast), Colin Breen (University of Ulster), and Nick Brannon (Queen's University Belfast).

Abstract: Contested understandings about the past continue to reify the divided character of post-Troubles Northern Ireland. In particular, the unresolved legacies of the extension of English control over Ireland in the late sixteenth and early seventeenth centuries through warfare and plantation continue to structure daily lives in the province. Yet the archaeological record of this period complicates the accepted dichotomous narratives through highlighting complexity. These nuances, however, have been lost in recent decades as an overly simplistic model of colonizer versus colonized has emerged as the dominant political paradigm. The management and presentation of sites associated with the process of plantation can arguably create the space necessary to bridge the divide, and to challenge accepted understandings. Cross community engagement in the process of archaeological discovery and interpretation on plantationperiod sites in Northern Ireland highlights the critical role archaeology can play in peace and reconciliation in post-conflict societies.

Keywords Northern Ireland, archaeology, peace building, identity, conflict, education, the Troubles

\section{Introduction}

The importance of heritage to the sphere of peace building in divided societies is increasingly recognised, and has a key role to play in conflict resolution in post-Troubles Northern Ireland. In 2005 ICCROM (International Centre for the Study of the Preservation and Restoration of Cultural Property, headquartered in Rome) held a pioneering seminar examining the role of cultural heritage in post-war recovery (Stanley-Price, 2005). Themes examined included the importance of identity, memory and the promotion of both tangible and intangible heritage during both conflict and post-conflict situations. Education plays an integral part in process of embedding heritage in such conflict resolution exercises. For example, the Lebanese nongovernmental organisation BILADI has developed a series of integrated programmes targeted at school children and professionals promoting built heritage as a mechanism to promote a cohesive national identity and build peace both in Lebanon and across the Middle East (Biladi, 2014). Further, restoration of monuments such as the rebuilding of the Old Mostar Bridge can serve as a highly symbolic act of reconciliation and connective process that demonstrates both the importance and potential of including heritage within peace-building initiatives (Hromadžić, 2008). However, much of the existing archaeological literature regarding conflict pertains to the protection of material remains during war, illicitly trafficked artefacts and the preservation of the 
resource following the cessation of violence. While these are important themes we would like to move beyond the boundaries of resource management and examine the potential for a more proactively engaged archaeology in Northern Irish society and further afield.

While the high level of violence has decreased and security has become 'normalised' contemporary Northern Ireland remains a divided society. Its communities drawn from the two main traditions, Catholic and Protestant, are increasingly divided along sectarian lines, educated separately and rarely mix, with segregation even more pronounced in working class communities Implicated in contemporary difference are the still contested and unresolved histories of the sixteenth and seventeenth centuries, when the English Crown extended military and political control over the island. Yet the archaeological record of this period complicates the accepted dichotomous narratives through highlighting complexity. The nuances of this complexity have been lost in recent decades as an overly simplistic model of colonizer versus colonized has emerged as the dominant political paradigm. The management and presentation of sites associated with the process of 'colonization' or plantation can arguably create the space necessary to bridge the divide, and to challenge accepted understandings. But how does one manage this process? Here, we wish to consider the importance of archaeological sites to local identities and communities and the role archaeology is playing in peace and reconciliation in post-conflict societies.

\section{Background}

Our shared research interests lie in the interplay of identities in the late medieval and post-medieval worlds of Ireland and Scotland, and the impacts of English Atlantic expansion on the political and cultural relationships throughout Britain and Ireland. The period of the sixteenth and seventeenth centuries was marked by the extension of British control over Ireland, through conquest and plantation- the intentional planting of loyal, mainly Protestant settlers on Irish lands. More often than not, archaeologists working on this period approach it as a purely 'academic' endeavour, focusing upon unearthing the 'facts' of the past without reference to their contemporary resonances. We are not content with that approach. We are acutely aware that the pasts we study carry unresolved legacies that were at the heart of the Northern Ireland Troubles ( $c$. 1968 c. 1998) and therefore are central to peace and reconciliation in the post-Troubles period.

The interactions between the Irish and the (mainly) English and Scots who settled in Ireland as part of the late sixteenth and early seventeenth-century processes of plantation remain contested and constitute the perceived root of the dichotomous historical memories that gave rise to thirty years of violence and which continue to structure everyday life. Very broadly drawn, contemporary Northern Irish society is dichotomous-divided between roughly equivalent populations that self-identity as either Catholic/nationalist, heir to the Gaels, or Protestant/unionist, heir to the English 
and Scots planters of the seventeenth century. Republicans and Loyalists, respectively, represent the aspirant voice of each community, while both communities self-identify as minorities (Nic Craith, 2002). The educational system continues to ensure divided identities. Notwithstanding a shared curriculum, over 90 percent of schoolchildren in Northern Ireland are educated in either maintained majority-Catholic or controlled majority-Protestant schools (McCully \& Barton, 2009; Hayes, et al., Dowd 2006). This makes public archaeology and active heritage interpretation all the more important insofar as we can reach out to diverse, intergenerational audiences in a non-threatening way.

Despite the functioning of the Northern Ireland Assembly, including the devolution of policing and powers of justice, and the overall 'normalisation' of life since the signing of the Good Friday Agreement in 1998, the Troubles are far from wholly resolved. Recent peace talks, chaired by US diplomat Richard Haass, aimed to deliver agreement over contentious issues including parades, Union flag-flying protests, and the legacy of thirty years of violence but ended in stalemate in late December 2013. Security alerts remain frequent and threats credible, as underscored by the explosion of what police describe as a 'firebomb', attributed to the New IRA, in the lobby of a Derry-Londonderry hotel in May 2014. Less tangible but no less significant are the psychological scars from the conflict, with a 2011 report (Ferry, et al., 2011) finding widespread and elevated rates of Post-Traumatic Stress Disorder across Northern Ireland, stemming from the reality that 39 percent of the adult population experienced a traumatic episode directly related to the conflict. It is against this context of societal division and continued low-level violence that we examine the potential role of archaeology both in contributing to understandings of the conflict but also addressing the part it can play in building peace and reconciliation.

\section{Archaeological insights and contemporary attitudes towards contested sites}

Ulster Plantation sites continue to exist in the present, with their meanings and associations renegotiated and reconsidered by each generation. The visibility and materiality of many Plantation monuments render them ready canvasses for political expression. One such example can be found in the surviving masonry walls of an aspirational H-plan Jacobean mansion boasting wide windows and massive chimney stacks built by an optimistic County Tyrone planter, Sir Toby Caulfield, in 1611-1616 (Jope, 1958; Brannon, 1999; Carver \& Donnelly, 2011). Architectural ambitions gave way to defensive realities when Castle Caulfield was attacked by Irish forces in 1641 and partially destroyed, never to be re-occupied. Today, surfaces on the prominent ruins are covered in Loyalist graffiti (Figure 1), possibly as an overt symbol of association with the plantation history of the site, and certainly as an assertion of local identity politics in the present. The building was also used as a canvas for a more overt response to the unrest which followed the Anglo-Irish Treaty of 1985. The exposed upper floors of the castle were painted with an outsize Union Flag that could not only be seen from the air, but from the surrounding countryside. 


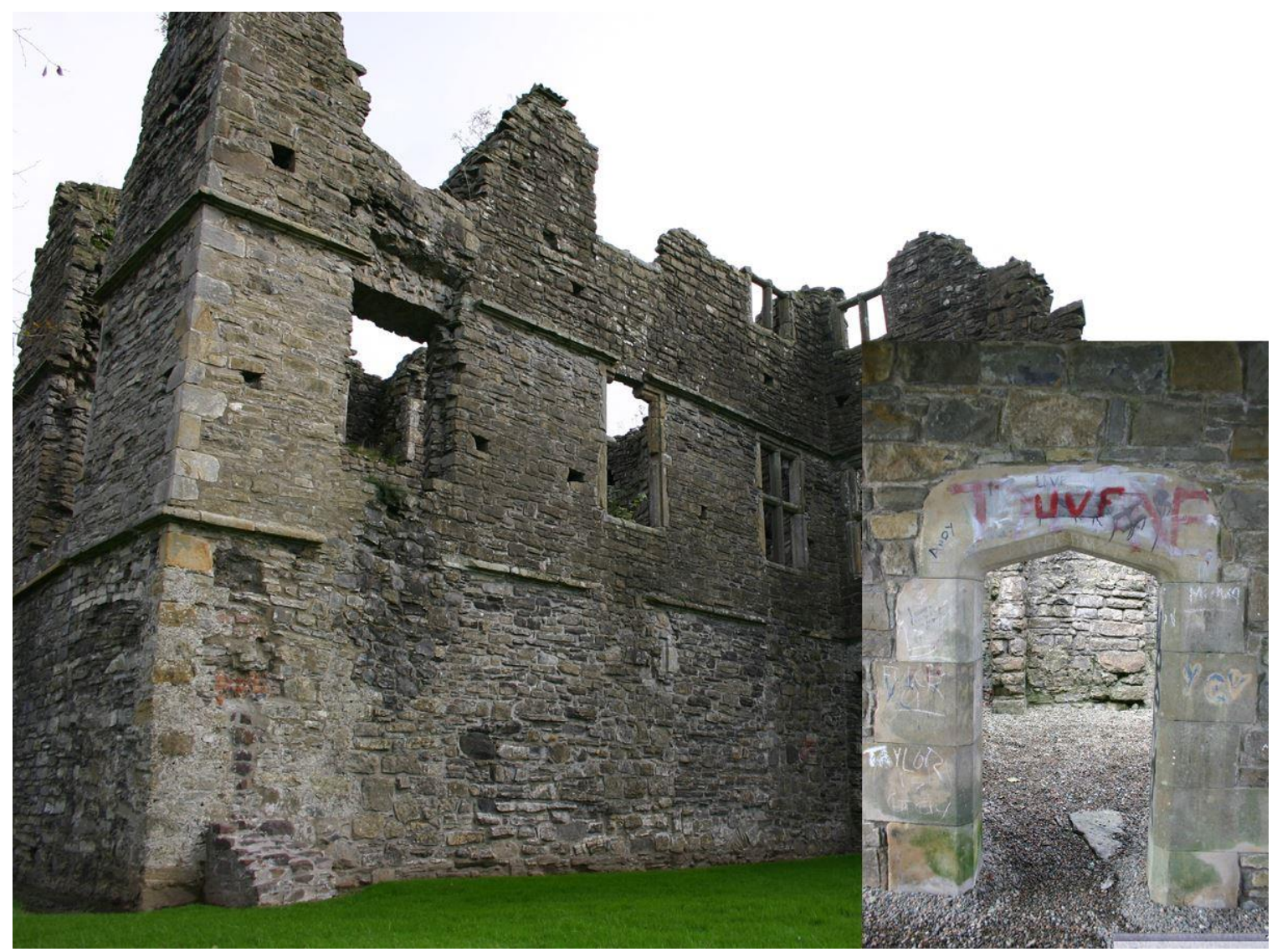

FIGURE 1 The ruins of Castle Caulfield, Co. Tyrone, with Loyalist graffiti shown as an inset.

\section{Source: Audrey Horning}

The walls of Derry-Londonderry are perhaps the most obvious example of a Plantation monument continuing to symbolically and physically exemplify division. As noted by archaeologist Brian Lacey $(2013,83)$, 'in the closing decades of the twentieth century, with their modern British Army security additions, the walls were still fulfilling some of the military and defensive functions for which they had been built in the first place.' While the military apparatus has been removed, the walls remain symbolic of separation and routinely attract politicised graffiti. Historic structures within the walls also continue to be targets for sectarian statements, exemplified by the paint-bombing of the historic 1780 First Derry Presbyterian church in 2011, just days before it was due to re-open following a $£ 2.5$ million refurbishment. Efforts to broaden appreciation of the historic walls featured in some of the events linked to the 2013 role of Derry-Londonderry as the UK City of Culture (City of Culture, 2013). However, while the walls are maintained by the Northern Ireland Department of the Environment, the fabric remains in the ownership of the London-based The Honourable the Irish Society- the consortium of London merchant guilds who first had the walls constructed from 1611 (Curl, 2000). Their continued involvement in Derry-Londonderry is a point of pride for the Irish Society, but the ongoing presence of the City of London undeniably adds an extra layer 
of complication to the evolution of a sense of cross-community ownership of the walls and the potential transformative power of renegotiating their meaning in the present.

Continuity of association is often a matter for local choice, as exemplified by the 'lost' plantation history of Dungiven Priory and bawn [fortified enclosure]. On the outskirts of the village of Dungiven, County Londonderry is the surviving fabric of a twelfth-century Augustinian Priory, now in state care. Associated with the ruins is a bullaun stone [large stone with scoop or hollow] repurposed as a holy well and a rag tree where the devout still tie strips of cloth to effect cures. Taken as a whole, the site evokes a sense of the continuity of medieval Gaelic tradition entirely in keeping with the outlook of the predominantly Nationalist local community. But a closer look at the physical fabric reveals a more complicated story (Figure 2). Part of the surviving walls relate to a medieval tower house constructed by the O'Cahans, the ruling Gaelic Lordship of what is now County Londonderry, who signalled their position in society through association with this holy site. Re-examination of the site in 1980 revealed that the entire site had been recast and redeveloped as the seventeeth-century bawn and castle of English planter Sir Edward Doddington, designated 'first farmer' of the Skinner's Company Proportion within the Londonderry plantation, and the man responsible for overseeing the construction of the Walls of Derry (Brannon \& Blades, 1980). Unlike Castle Caulfield, local knowledge of the association of Dungiven Priory with the Ulster Plantation appears to have been lost or wilfully obscured. Until the archaeological rediscovery of the bawn, even scholars assumed that Doddington's plantation house was situated near the late seventeenth/ early eighteenth-century Dungiven Castle within the present town (Davies, 1939; Rowan, 1979: 266). While the pre-Plantation, pre-Reformation history of the site appears reclaimed, the muted but nonetheless highly visible traces of Doddington's stronghold could arguably provide the first spark for a meaningful discourse about local history and identity. In the meantime, however, local tourism brochures and initiatives continue to emphasise only the pre-Plantation history of the site, even though government signage at the site clearly addresses its Plantation history. 


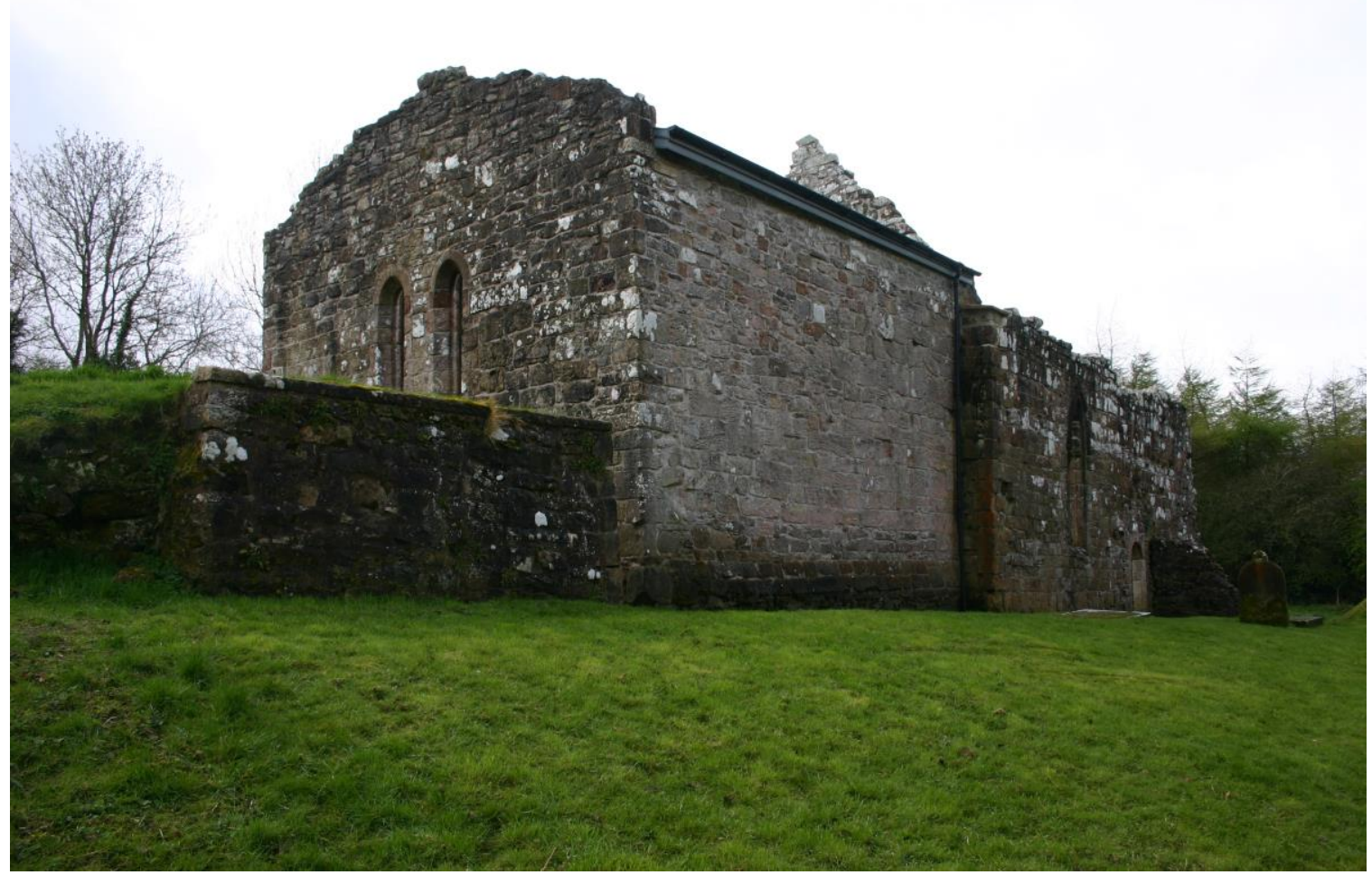

FIGURE 2 Dungiven Priory, Co. Londonderry.

\section{Source: Audrey Horning}

A similar situation prevails in the nearby Roe Valley Country Park, where the site of another O'Cahan tower house is a well-recognized local monument. Referred to as ' $O$ 'Cahan's rock' because of its situation on the edge of a cliff overhanging the River Roe, this O'Cahan site is also the location of the manor house and bawn [defensive wall] of one of the architects of the Londonderry Plantation; the English servitor Sir Thomas Phillips (Horning, 2013c). Again, government signage clearly identifies the site as Phillips's seat, but local memory emphasises its Gaelic association. In the case of both Castle Caulfield and Dungiven, local communities select the elements of their past that they choose to recognise in the landscape. Alongside obscuring the history of these sites, this process could also be read as denying minority members of the local community a tangible connection to a past to which they may feel a greater connection.

Another site associated with Thomas Phillips is not just actively forgotten, but has been intentionally targeted. In 1602, Phillips led English forces against Hugh O'Neill, capturing O'Neill's stronghold at Toome on the north shore of Lough Neagh. Excavations in 1991 (Ó Baoill, 1999) uncovered the traces of Phillips's re-edification, but suffered from repeated instances of vandalism from members of the local Nationalist community of Toome that only ceased with the intervention of the local priest. Today, the castle site itself is unmarked and evidently unremarked; situated alongside a redeveloped path alongside a restored portion of the nineteenth-century Bann Navigation. While the 
former presence of a castle is acknowledged on a general interpretive sign for the towpath, there is no signage at the castle site. Instead, the slight depression still remaining from the excavation serves as a receptacle for unwanted household rubbish in what might be viewed as an ongoing editorial comment on the past.

Even earlier sites associated with English 'colonial' activities are employed to convey and potentially legitimise sectarian sentiment. Clough Castle, Co. Down, was built in the late twelfth century as a motte and bailey fortification by the invading Anglo-Normans (Archaeological Survey of Northern Ireland, 1966: 200-203, 233). Although a monument in state care, locals erected a flagpole on the site from which the Union Flag is still routinely flown, while the masonry walls of the sixteenth-century tower house built within the Anglo-Norman keep frequently are subjected to loyalist graffiti such as the phrase 'No Surrender.' In short, some monuments of the past acquire the symbolism of the present.

Far more problematic are monuments of the most recent past. Evocative material reminders of the Troubles, such as Army checkpoints and watchtowers, are routinely neutralised through removal or reconfiguration, often without record or archaeological input. While disassembling the apparatus of conflict is overwhelmingly welcomed, simple removal does not bring reconciliation. The retention of selected structures could be employed to facilitate remembrance and forgiveness, but to date that has not been a widely supported action. A particular case in point is that of Long Kesh/Maze Prison outside of Belfast, as discussed by Laura McAtackney (2014). Between 1971 and 2000, Long Kesh/Maze served as the principal facility incarcerating both Republican and Loyalist prisoners on Troubles-related offences. Most notoriously the locale of the 19801981 Hunger Strikes, which claimed ten Republican lives, the prison was also ultimately the location for the start of the prisoner-led negotiations that eventually led to paramilitary ceasefires. As debate over the future of the site continues, much of the fabric, including the iconic H-blocks, has been systematically removed. In late 2013, plans to build a peace centre were placed on hold in the face of Unionist fears that it was a thinly-veiled attempt to create a shrine to Republican martyrdom. Whatever the future for the site and the few remaining structures, as McAtackney (2014: 278) notes, 'to pretend to forget Long Kesh/Maze is not a viable option.'

\section{Engaging with material evidence: Conflict resolution and heritage in Northern Ireland}

What role can archaeological sites play in conflict resolution? Conflict is a deeply complex phenomenon with multiple and interlinked root causes. Among the central facets of many conflicts across the globe are historical power relations where particular groups advocate for cultural or political supremacy over other groups (Jeong, 2000: 32). This deliberate marginalization or creation of insider versus outsider groups is a characteristic of the colonial process and a key factor in the emergence of horizontal 
inequalities across society. The primary analytical tool for interpreting these processes has been historical research. Archaeology, however, seldom plays any role in either conflict analysis research or resolution processes but can and should play a significant part in both. One of the central tenets in the escalation of conflict in Northern Ireland was the emergence of dual narratives rooted in the recent historical past. However, what archaeology is telling us about the character of relations between the Gaelic worlds of the north of Ireland and the Scottish isles with that of the encroaching Lowland Scots and English planters challenges and even reverses long held historical narratives that provide the foundation for ingrained sectarian beliefs - the same narratives that also inform conflict analysts.

Insights from research on late medieval and plantation-period sites highlight the complexity of cultural interactions in the period and reveal material evidence for the emergence of shared, syncretic practices drawing upon Irish, Scottish, and English traditions. Physical evidence for shared practice in the plantation period includes the presence of Irish vernacular buildings and ceramic vessels in English plantation villages (Horning, 2001); early plantation-period settlements with diverse populations (Breen, 2012a); the adoption and subversion of English polite architecture by the Gaelic elite (Donnelly, 2005); the mimicking of Gaelic hospitality rituals and use of associated material culture by the planter elite (Horning, 2013b); the reuse of medieval raths [ringforts] and crannogs [artificial islands] by settlers (Brady \& O' Conor, 2005); and continuity in pre-plantation settlement patterns and landscape use, accompanied by documentary analysis highlighting routine interaction between indigenous Irish and incoming settlers (Breen, 2012b; Donnelly, 2007; Donnelly \& Horning, 2002; O'Keeffe, 2008). In the present, such tangible evidence possesses a profound capacity to challenge understandings of the divide between Irish and British identities and contribute to the emergence of a shared Northern Irish identity. The peace process has created the space needed to more openly and overtly consider the ramifications of such evidence in public fora.

Archaeological evidence clearly highlights the incomplete and chaotic nature of the Plantation process and exposes the ambiguity in relations between natives and newcomers. Lessons for the present can certainly be drawn from this past, but how should such a process be structured? We have had an opportunity to explore and develop an approach to the integration of archaeology with conflict resolution over the last seven years, in relation to a range of four hundredth anniversaries of key episodes of plantation, from the 1607 Flight of the Earls, to the formal launch of the Ulster plantation in 1609, and the granting of town charters to key plantation settlements in 1613. Local authorities are charged with marking the anniversaries of these events in a society where there is no agreed historical narrative and where divergent understandings are held by two groups of roughly equivalent power. Working with local authorities in bringing community groups together to explore the archaeology associated with these anniversaries has had a positive effect on cross community dialogue. This is underscored by comments from Belfast City Council describing 
archaeology as 'a vital tool because it exemplifies shared history and often impacts on and challenges the facile dichotomies which dominate popular understanding' (Belfast City Council, 2013).

Place-based local initiatives are particularly effective through embedding engagement and conflict resolution in the practices of archaeological fieldwork and material interpretation. Involvement in the archaeological process itself can both help to build and make peace in society, because it allows for the integration of community and individuals into the recovery of their own narratives as they confront for themselves physical evidence that contradicts accepted histories. While not without its risks, the excavation process can emerge as transformative; serving as a place for meditative reflection on conflict and acting as a place for negotiation and joint working in a nonpartisan environment.

The multiple plantation anniversaries of recent years have provided useful opportunities for leveraged funding towards public engagement in historical archaeology and the multiple 'heritages' which it can illuminate. European-funded initiatives have employed the monuments of plantation as a means of encouraging understanding and discourse about the histories behind the controversial plantation anniversaries. Such activities range from tours, facilitation of community groups developing their own heritage projects, and full inclusion of community members on archaeological research projects.

For example, in the context of the four hundredth anniversary of urban incorporation in 1613, under James I, the north-coast Causeway Museums Services obtained European 'Peace III' funding to support numerous public tours of the Londonderry Plantation town of Coleraine and other sites including Dungiven, escorted by historical archaeologists. Tours within the town of Coleraine illuminate the survival of its Plantation street pattern and its medieval church, reconnecting the present urban environment, filled with shops but deserted at night, with the more chaotic appearance of its seventeenth-century manifestation. One local history group, self-identifying as working-class Protestant, radically revised its own historical narrative of urban Coleraine when confronted by the archaeological evidence of an undocumented tannery operating within one block of the town centre, in blatant, noxious contravention of urban bye-laws, and contradicting received histories of the careful application of Plantation civic ideology. Archaeological evidence from Coleraine also contradicts another local urban myth, enshrined in the Irish Society's three hundredth anniversary stained-glass window housed in the Town Hall, that timber-framed houses present in Coleraine in 1610 were imported, readymade, from London. In reality, as demonstrated through excavation and dendrochronology, these structures were constructed of local materials, by local (likely Irish as well as English) labourers (Brannon, 1985, 1988; Robinson \& Brannon, 1983).

The Peace III tours also took participants to Dungiven, where the 'hidden' plantation history of the site was the focus of discussion and discovery. A feature of these visits was allowing access to the chancel of the church, not usually open to visitors, to see the 
rare survival of a fifteenth-century effigy tomb erected by the O'Cahans (Figure 3 ). The special viewing and the opportunity to 'touch' the past inevitably provoked discussion of why Doddington chose to not to destroy the O'Cahan tomb, clearly a Catholic, Irish symbol, and instead allowed it to feature within his newly-restored Protestant church. Given the routine removal and destruction of similar such tombs in other religious houses as part of the process of Reformation, Doddington's inaction was clearly deliberate. Was he sympathetic or just indifferent to Catholicism, or pragmatically situating himself, like the O'Cahans, as rooted in the antiquity and holiness of the site? Whatever the explanation for Doddington's choice, the survival of the tomb forces a rethink of the role of sectarianism and religious violence in the implementation of Plantation.

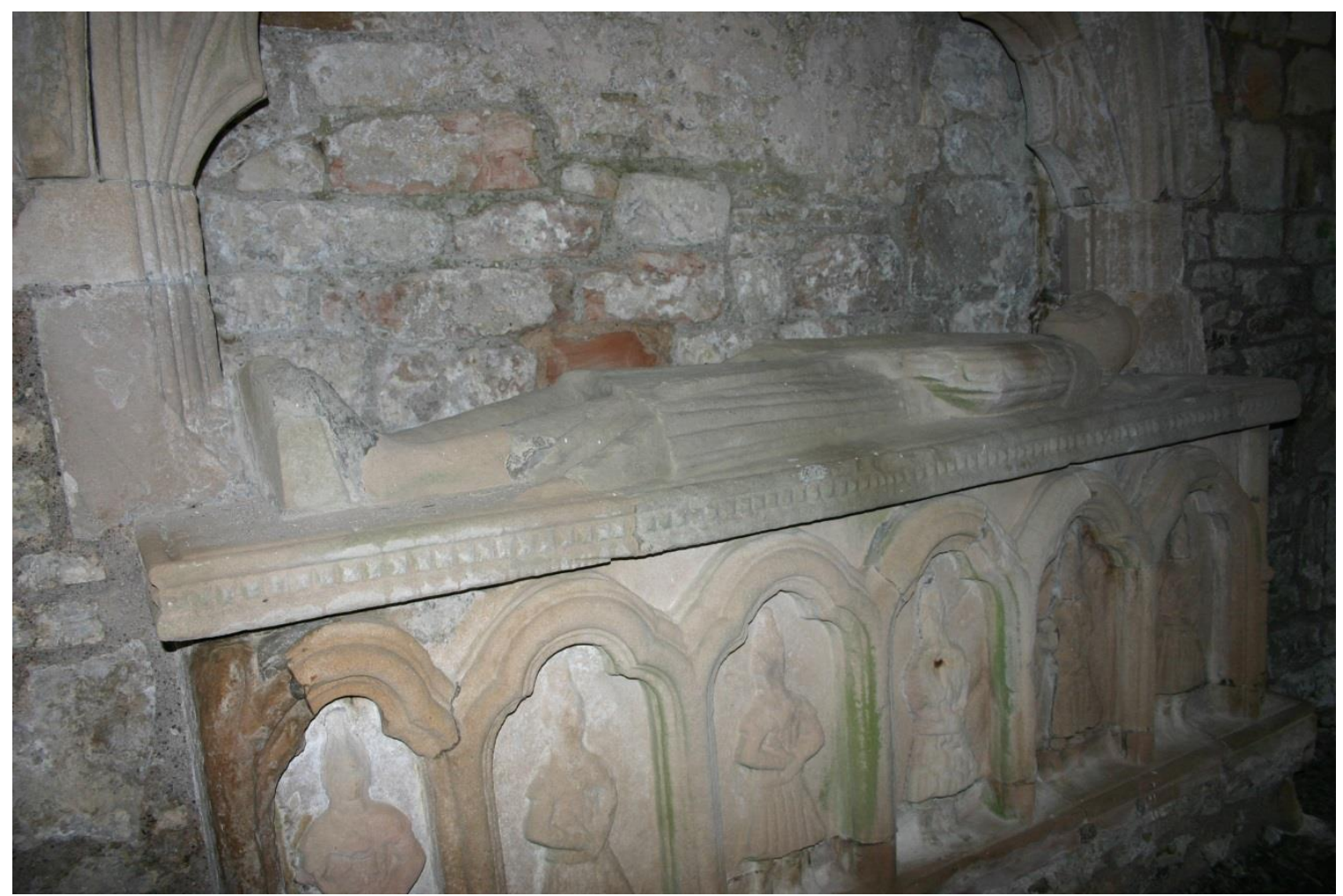

FIGURE 3 The O'Cahan effigy tomb in the church at Dungiven Priory.

\section{Source: Audrey Horning}

European funding for such projects required accountability and auditing. The selfselecting (free trips for all, on request) audience was invited to answer questionnaires designed to reflect the impact of historical archaeological approaches. From the responses to questions such as 'did you learn anything that surprised you?', the point was clearly made: 'There are people with real stories behind the guise of a history which has been contorted by personal views;' 'Insight into how archaeology enhances/ changes our view/ knowledge of history'; 'History is much more complex!;' 'We need to 
re-visit our understanding (pre-conceived ideas) about the whole process of the plantation.'

Several community-engaged archaeological projects were conducted in and around Derry/Londonderry as part of the city's UK City of Culture activities, intentionally bringing together community groups from Northern Ireland and across the border in the Republic of Ireland. For example, excavations were conducted at Dunnalong, Co. Londonderry near the Donegal border, with funding from the European Union's Peace III project (Derry City Council, 2013). The site itself was once a key Gaelic holding that was captured and refortified by English forces during the Nine Years' War of the late sixteenth century. Once a locus for past conflict, the site was transformed into a temporary centre for cross-community, cross-border engagement and shared discovery. As part of the Derry-Londonderry UK City of Culture programme, excavations funded by the Northern Ireland Environment Agency (NIEA) were conducted within the walled city and incorporated local community volunteers; also attracting wide media coverage and interest. The recovery of seventeenth-century human remains at Bishop Street Within inevitably sparked discourse about conflict in the past, while the finding of miniature bone dice in association possibly associated with English soldiers stationed in the seventeenth-century city, served as a tangible connection to the more quotidian aspects of past experience (Murray \& McSparron, 2014).

In another example, local school and community groups were invited to take part in the excavation of the early seventeenth-century village associated with Dunluce Castle (Figure 4), one of Northern Ireland's most iconic monuments and once the centre of the later medieval MacDonnell Lordship (Breen, 2012a). In addition to removing professional mystique, engagement with the physicality and surprises of the past can facilitate difficult conversations. Some of the surprising histories emerging from the Dunluce soil that provoked such conversations include the manner in which the Catholic Randal MacDonnell, named earl of Antrim by his fellow Scot King James I, emulated the economic activities of other early modern, predominantly English, entrepreneurs. MacDonnell designed the town outside of his castle as a commercial hub for the north coast, and redesigned his manor house after the English fashion. MacDonnell also actively planted his lands with settlers, many of whom were Scottish but not all of whom were Protestants. MacDonnell himself was Catholic and actively supported the Franciscans, but he also supplied his tenants with a purpose-built Protestant church. By the mid part of the century, the town's residents were predominantly Irish and it could not have been realistically regarded as a 'planter town'. 


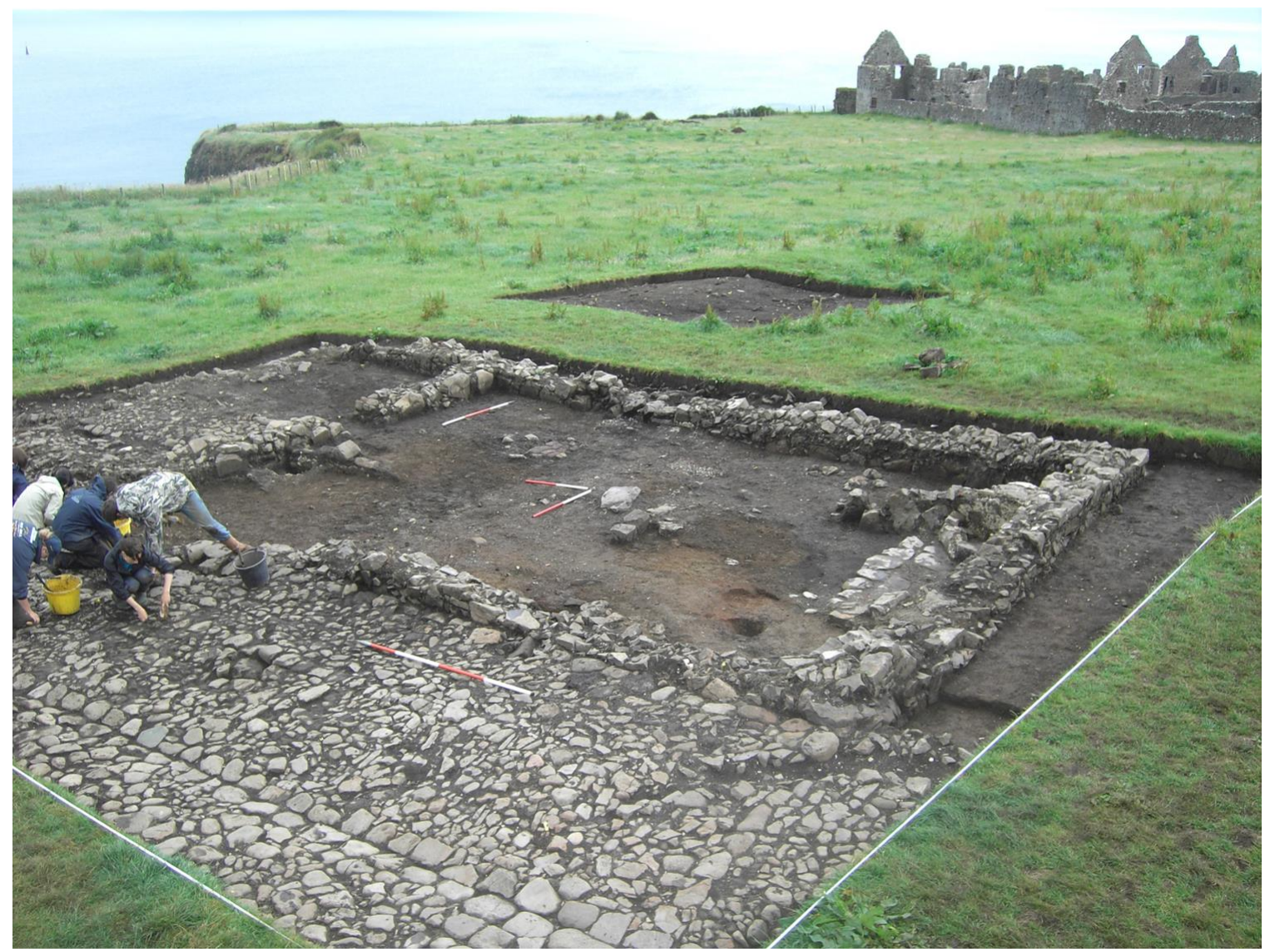

FIGURE 4 Excavations in the village adjacent to the walls of Dunluce Castle.

\section{Source: Colin Breen}

The MacDonnells themselves came from an exclusively 'Gaelic' background but were very adept at renegotiating the cultural context of their identity-sets in light of the prevailing political fashions of the day. Those who participated in the Dunluce and other excavations must reconcile those revelations with their own senses of history, framing a new understanding through a process of remembering and forgetting. The many community and school groups who came to excavate at Dunluce were welcomed as an integral part of the project team and were directly involved in the recovery of past material culture in a non-prescriptive environment. Constant archaeological questioning and re-evaluation on site illustrated the complexity of interpreting the past and allowed for the introduction and understanding of multi-vocality and the multi-layered narratives that constitute our understandings of the past. As expressed by one of the community groups engaged in the Dunluce work and related projects, the Ballintoy and District Local Archaeological and Historical Society (2013), 'the knowledge we gained of the complicated nature of the Plantation period challenged our previously held views. Members ... from different backgrounds are now more willing to discuss the impact of the Plantation... willing to reconsider their own identities in light of what they have learnt through engaging with professional archaeologists... gave us the confidence to tackle sensitive issues ...helping to improve community relations and assist conflict 
resolution'. From these comments, and others, it is clear that the physical engagement with the discovery process allows individuals to make up their own minds, in their own time, about the significance of the evidence. This is not a process to be controlled by heritage professionals, but it is one that we can set into motion.

\section{Reconsidering the heritage of Ulster and the Scottish isles}

A collaborative network of university researchers, museums and government bodies collectively known as IAASC (Integrating Archaeology and Sustainable Communities, 2014) is further examining the role of heritage in conflict resolution and in building community cohesion through the development of a best-practice model of community learning and engagement. A particular focus is working with local communities in Northern Ireland and western Scotland to reconnect the two locales with their shared heritage. In the medieval period, North East Ulster and the Western Isles were intrinsically linked by a common set of cultural traditions, language and political structures. These connections are best exemplified by the political world of the maritime MacDonnell Lordship, which encompassed much of the Isles and incorporated the north coast of county Antrim with its centre at Dunluce. Efforts by the MacDonnells to extend and retain political control are materially marked by a series of castles and fortifications along the coast of County Antrim and throughout the Isles. English political commentators of the sixteenth century routinely lamented the influence of the Highland Scots in Ulster, particularly their affinity with the population and culture of Gaelic Ulster. In recent history, these connections have all but disappeared, so we aim to build awareness of this shared past, creating opportunities to explore, question and share historic narratives across community boundaries and between generations (Horning 2013a).

Our focus on the connection between the north of Ireland and the Scottish isles is also directly relevant to peacebuilding in Northern Ireland. Within the Unionist community, some of the most influential voices are those of individuals whose ancestors came to Ulster from lowland Scotland, many of them professing nonconformist faiths dominated by variants of Presbyterianism. Their historical understanding of the plantation period is one in which their ancestors came to a wasted, depopulated land - a terra nullius- and then transformed it into an agricultural and later industrial powerhouse. This wilderness myth was taken up by the twentieth-century historian ATQ Stewart who wrote '...Hamilton \& Montgomery... did not wrest a fertile, cultivated and prosperous region from Gaelic proprietors. They came instead to a country devastated by war and famine... they created the bridgehead through which the Scots were to come into Ulster for the rest of the century...' (Stewart, 1977: 38-9). While the majority of Presbyterian Scots actually came to Ulster in the late seventeenth century, in constructed memory it is the early seventeenth-century plantation period that resonates.

Over the last decade, and as part of the peace process, an Ulster Scots identity has emerged as a counterpoint to an Irish nationalist identity. Part of this new construction has centred on the formalisation of an Ulster Scots language, derived from Lowland 
Scots speech. Funding for the promotion of Ulster Scots language and heritage is provided by the Department of Culture, Arts and Leisure to the Ulster Scots Agency, or Boord $O$ Ulstèr Scotch, in parity with support for the Irish language body, Foras na Gaeilge. The provisions of the 1998 Good Friday Agreement and the 2006 St Andrews Agreement emphasise the need for parity between the two traditions, but in so doing, effectively facilitates the enhancement of difference rather than facilitating and promoting elements of shared cultural heritage. We are not arguing that the dual traditions should be discarded and replaced by a homogenous singular collective, but we do query the overt politicisation and increased separation of the two traditions which alienates and sidelines many elements of past commonalities and the concept of a shared past. That the new construction of Ulster Protestant identity as a uniquely Scottish inheritance ignores the considerable English impact on Ulster society remains unresolved, while the influence of Highland, Catholic Scots in Ulster, both before, during, and after plantation, is similarly an awkward topic that is avoided.

Historical sites and monuments invariably become implicated in the battle for parity of esteem. Considerable quantities of government funding are available for Ulster Scotsthemed projects. Some of this money supports genuine historical research, but in other cases has precipitated the conscious and often cynical re-attribution of sites and landscapes as especially or even exclusively 'Ulster Scots' in character. Emphasising the particularly Ulster Scots nature of Ulster invariably makes a political point justifying the continued separation of the province from the rest of Ireland, as underscored by this quote from a student education pack on Ulster Scots history (Ulster Scots Agency, 2013) focusing on the unique identity of the Presbyterian settlers: 'All these differences made these Ulster-Scots stand out as different. Over time it would make the north-east part of the island culturally very different from the rest of Ireland.'

This assertion dovetails with contemporary Unionist political philosophy, which emphasises the differences between north and south and also involves the archaeology of earlier periods to promote separation. For example, a series of interrupted Iron Age linear earthworks running roughly from Co. Donegal to Co. Monaghan have been used by contemporary unionist politicians in Northern Ireland to justify the continued separation of the six counties from the Republic. Extrapolating well beyond the archaeological evidence, one Lisburn history website refers to these earthworks as the 'great walls of Ulster' which helped to protect 'the essential ancient Britishness of the Ulster homeland [and shows] that the Gaelic Irish, who today claim to be the true Irish and rightful heirs to the land, were nothing other than yet another wave of invaders' (Lisburn, 2014). Ulster Unionist David Hume further proclaimed the earthworks as proof that 'The ancient history of Ulster... underlines the essential fact which Irish nationalists conveniently ignore: Ulster has always been different from the rest of Ireland. And it always will be'. (quoted in Warner, 1999).

Few, if any, of these 'differences' withstand the rigours of detailed historical and archaeological scrutiny. Unfortunately this paradigm of difference has also begun to appear in the conflict analytical reports. The respected peace researcher John Darby 
wrote in 2003 that 'Protestant settlers lived in close proximity to the Catholic Irish who were cleared to the geographical margins but not exterminated. Within several generations the broad outlines of the conflict had been established. The territory contained two groups who differed in political allegiance, religious practice and cultural values. One group believed that their land had been stolen, while the other was in a constant state of apprehension. Northern Ireland still suffers from the problems of rival ethnic groups living cheek by jowl and in suspicion of each other'. Following a similar theme Holloway's 2005 report on Understanding the Northern Ireland Conflict asserted that '...Native Irish and Plantation settlers existed in a state of mutual hostility that has, to an extent, continued to the present day'.

The Scottish heritage of Ulster is very important- but its importance is not just relevant to one community. In the complexities of the late medieval relationship between the two lands and their peoples may be found the seeds for genuine reconsideration of and perhaps even rejection of the historical tropes that force fit the cultural entanglements of Ulster into two dichotomous narratives to be treated as separate but equal.

\section{Conclusion}

The past remains a deeply contested arena in Northern Ireland, and it is imperative that archaeologists engage with the challenges posed by current separatist cultural developments. Archaeology has much to say about the past and the process of archaeological research has the potential to integrate into peace building programmes. From this perspective archaeological sites and the archaeological process itself could be utilised in a far more proactive sense to promote shared understandings of the past and reconciliation. Excavations and archaeological projects can function as a process of the joint recovery of narratives. Archaeological sites, places or excavations can serve as shared spaces where dialogue is encouraged through informed and participatory investigation.

The Peace Museum movement is of particular interest in this regard. These museums are innovative learning spaces operating on a number of differing levels including physical, sociocultural and personal spaces (Ramsbotham et al, 2011: 347). Globally these centres vary from interpreting particular narratives to sites of memory or places of reconciliation. Van den Dungen $(2008,17)$ has argued that each share a common value of forwarding 'an alternative voice or resistance to the dominant and dominating voices of violence'. If we move beyond the physicality of the architectural space of a museum building then a more abstract or 'pop-up version' of a peace museum can be envisaged for an archaeological site or project. The physical process of archaeological investigation presents the survey participant or visitor the opportunity to investigate the past in a shared, open and interrogative environment. It allows to individual to understand the process of historical investigation and interpretation in what is, by its very nature, an inclusive and emotive environment. 
Existing historical narratives have been constructed and construed over many generations for many different purposes using a limited resource base. This is essentially an abstract process, often conducted at a physical and metaphorical distance from the communities of Northern Ireland. By contrast, archaeological sites of the chronological period under study here are physically present in all areas of the Ulster landscape and are readily accessible by the people who live and work in the local area. Discursive and immersive programmes of community investigation of these sites and their associated material culture could bring a series of field peace museums into reality and allow for the investigation and discovery of a community's past in a shared and common heritage space through the transformative archaeological process. The mutual recovery of shared narratives allows for the production of more nuanced understandings of the past and side-lines the artificially constructed agenda-laden voices of certain groups.

\section{Bibliography}

Archaeological Survey of Northern Ireland. 1966. An Archaeological Survey of County Down. Belfast: Her Majesty's Stationery Office.

Ballintoy and District Local Archaeological and Historical Society. 2013. Letter to Queen's University Belfast, 26 August.

Belfast City Council, Development Department. 2013. Letter to Queen's University Belfast, 30 August.

Biladi, 2014. This is Biladi [online] [accessed 11 May 2014]. Available at: http://thisisbiladi.com/.

Brady, N. \& O'Conor, K. 2005. The later medieval usage of crannogs in Ireland. Ruralia $\mathrm{V}$, 127-136.

Brannon, N.F. 1985. Excavations in New Row, Coleraine. In: G. Egan ed., Post-Medieval Britain and Ireland in 1984. Post-Medieval Archaeology 19, p.168.

Brannon, N.F. 1988. Where history and archaeology unite: Coleraine, Co. Londonderry. In: A. Hamlin \& C. Lynn, eds. Pieces of the Past. Belfast: Her Majesty's Stationery Office, pp. 78-79.

Brannon, N.F. 1999. Archives and Archaeology: The Ulster Plantations in the Landscape. In R.L. Michael and G. Egan, eds. Old and New Worlds. Oxford: Oxbow, pp. 97-105.

Brannon, N. F. \& B. Blades. 1980. Dungiven Bawn re-Edified. Ulster Journal of Archaeology 43, pp. 91-96.

Breen, C. 2012a. Dunluce Castle, History and Archaeology. Dublin: Four Courts. 
Breen, C. 2012b. Randal MacDonnell and early seventeenth-century settlement in northeast Ulster, 1603-30. In O Siochru \& E. O Ciardha, The Plantation of Ulster: ideology and practice. Manchester: Manchester University Press, pp. 143-157.

Carver, N. \& Donnelly, C. 2011. Investigations at Castle Caulfield, Lisnamonaghan, Co. Tyrone. Belfast: Queen's University Belfast. Report submitted to the Northern Ireland Environment Agency.

City of Culture, 2013. [online] [accessed 11 May 2014]. Available at: http://www.cityofculture2013.com/2013-programme/.

Curl, J. S. 2000. The Honourable the Irish Society and the Plantation of Ulster, 1608-2000 London: Phillimore.

Darby, J. 2003. Northern Ireland: The background to the Peace Process. Coleraine: CAIN, University of Ulster.

Davies, O. 1939. Dungiven Priory. Ulster Journal of Archaeology 2, 271-287.

Donnelly, C. 2007. The Archaeology of the Ulster Plantation. In: A. Horning, R. O'Baoill, C. Donnelly \& P. Logue, eds. The Archaeology of Post-Medieval Ireland, 1550-1850, Dublin: Wordwell, pp. 37-50.

Donnelly, C. 2005. The I.H.S. monogram as a symbol of Catholic resistance in 17thcentury Ireland. International Journal of Historical Archaeology 9(1): 37-42.

Donnelly, C. \& Horning, A. 2002. Post-Medieval and Industrial Archaeology in Ireland. Antiquity 76 (292), pp. 557-561.

Ferry, F., Bolton, D., Bunting, B., O’Neill, S., Murphy, S. \& Devine, B. 2011. The Economic Impact of Post Traumatic Stress Disorder in Northern Ireland. www.nictt.org.

Hayes, B.C., McAllister,I. \& Dowds, L. 2006. In Search of the Middle Ground: Integrated Education and Northern Ireland Politics. The Ark, Research Update 42.

Holloway, D. 2005. Understanding the Northern Ireland Conflict: A summary and overview of the conflict and its origins. Belfast: The Community Dialogue Critical Issues Series, Vol. 3.

Horning, A. 2001 Dwelling houses in the old Irish Barbarous Manner': Archaeological evidence for Gaelic Architecture in an Ulster Plantation village. In: P. Duffy, D. Edwards, and E. Fitzpatrick eds., Gaelic Ireland 1300-1650: Land, Lordship, and Settlement., Dublin: Four Courts Press, pp. 375-396 
Horning, A. 2013a. Exerting influence? Responsibility and the public role of archaeology in divided societies. Archaeological Dialogues 20(1), pp. 19-29.

Horning, A. 2013b. Ireland in the Virginian Sea: Colonialism in the British Atlantic. Chapel Hill: University of North Carolina Press.

Horning, A. 2013c. Leim an Mhadaigh: Exploring 'unwanted' histories of the Atlantic World. In: P. Pope \& S. Lewis-Simpson, eds. New World Transitions. Woodbridge, Suffolk: Boydell and Brewer, pp. 93-102.

Hromadžić, A. 2008. Discourses of Integration and Practices of Re-unification at the Mostar Gymnasium, Bosnia-Herzegovina. Comparative Education Review 52(4), pp. 541563.

IAASC, 2014. Integrating Archaeology and Sustainable Communities [online] [accessed 11 May 2014]. Available at: <www.iaasc.com>.

Jeong, H-W. 2000. Peace and Conflict Studies, an Introduction. Surrey: Ashgate.

Jope, E.M. 1958. Castlecaulfield, Co. Tyrone. Ulster Journal of Archaeology 21, pp. 107108.

Lacey, B. 2013. The Archaeology of the Plantations in Ulster. In: E. Klingelhofer, ed. A Glorious Empire: Archaeology and the Tudor-Stuart Atlantic World. Oxbow, Oxford, pp. 79-90.

Lisburn Borough Council. 2014. Lisburn history [online] [accessed 11 May, 2014]. Available

at: <http://www.lisburn.com/history/history lisburn/settlement of ulster.htm>.

McAtackney, L. 2014. An Archaeology of the Troubles: the Dark Heritage of Long Kesh/ Maze Prison. Oxford: Oxford University Press.

McCully, A. \& Barton, K. 2009. When history teaching really matters: understanding the intervention of School History on students' neighbourhood learning in Northern Ireland. International Journal of Historical Learning and Teaching Research 8, pp. 28-46.

Murray, E. \& McSparron, C. 2014. LegenDerry Digs. Archaeology Ireland 28 (1), pp. 3538.

Nic Craith, M. 2002. Plural Identities, Singular Narratives: the case of Northern Ireland. New York: Bergdahd Books. 
Ó Baoill, R. 1999. Excavations at the Site of Toome Castle, Co. Antrim. Ulster Journal of Archaeology 58, pp. 90-108.

O'Keeffe, J. 2008. The Archaeology of the Later Historical Cultural Landscape in Northern Ireland: Developing historic landscape investigation for the management of the archaeological resource: A case study of the Ards, County Down. Unpublished PhD thesis, University of Ulster, Faculty of Life and Health Sciences.

Ramsbotham, O., Woodhouse, T. \& Miall, H. 2011. Contemporary Conflict Resolution. Cambridge: Polity.

Robinson, P. \& Brannon, N. 1983. Some late survivals of Box-Framed 'Plantation Houses' in Coleraine. Ulster Journal of Archaeology 46, pp.129-136.

Rowan, A. 1979. North-West Ulster: the counties of Londonderry, Donegal, Fermanagh, and Tyrone. New Haven: Yale University Press.

Stanley-Price, N. 2005. Cultural Heritage in Postwar Recovery. Papers from the ICCROM FORUM. Rome: International Centre for the Study of the Preservation and Restoration of Cultural Property.

Stewart, A. T. Q. 1977. The Narrow Ground: Patterns of Ulster History. Bangor, Co. Down: Pretani Press.

Ulster Scots Agency 2013 Ulster Scots Heritage on the Landscape: A pupil's booklet. [online] [accessed 11 May, 2014]. Available at:

<http://www.ulsterscotsagency.com/fs/doc/teaching-resources/landscapeheritagepupil-booklet.pdf $>$.

van den Dungen, P. 2008. Museums for Peace: Past, Present and Future. In: I. Anzai, J. Apsel \& A. Mehdi. eds. Museums for Peace: Past, Present and Future. Kyoto, Ritsumeikan University, pp. 17-25.

Warner, R. 1999 Celtic Ireland and Other fables: Politics and Prehistory. Paper presented to the 1999 Irish Association Conference, Carrickfergus. [online] [accessed 11 May, 2014]. Available at: <http://www.iol.ie/ ritechne/century130703////1990s/irishassoc/warner.htm>. 